\title{
KAJIAN DESKRIPTIF PENYELENGGARAAN KURIKULUM MUATAN LOKAL BAHASA USING DI SEKOLAH DASAR BANYUWANGI
}

\author{
Andrea Yurista Tyasari, Anselmus J. E. Toenlioe, Yerry Soepriyanto \\ Universitas Negeri Malang, Jalan Semarang 5 Malang 65145 \\ E-mail: kalabtep@gmail.com
}

\begin{abstract}
A Descriptive Study of Implementating “Using” Language as a Local Content Curriculum at SDN Kertosari 1 Banyuwangi. The purpose of the study to illustrate the local content component planning of the curriculum also describes the implementation of local content curriculum in schools. This research use desciptive qualitative approach. The results show that implementation of local content in primary schools has many obstacles. Issues in the implementation of local content curriculum to date relate to all aspects of planning, implementation and evaluation. At this time it is imperative that a review of local content curriculum implementation of the Language of Use and requires evaluation as well as comprehensive updating. Research will provide input on existing programs.
\end{abstract}

Keywords: curriculum evaluation, local content curriculum, “using” language

\begin{abstract}
Abstrak: Kajian Deskriptif Penyelenggaraan Kurikulum Muatan Lokal Bahasa Using di SDN Kertosari Banyuwangi. Tujuan penelitian untuk menggambarkan perencanaan komponen muatan lokal kurikulum juga mendeskripsikan pelaksanaan kurikulum muatan lokal di sekolah. Penelitian ini menggunakan pendekatan deskriptif kualitatif. Hasil penelitian menunjukkan implementasi muatan lokal di sekolah dasar memiliki banyak hambatan. Persoalan dalam implementasi kurikulum muatan lokal sampai saat ini berkaitan dengan semua aspek perencanaan, pelaksanaan dan evaluasinya. Saat ini sangat perlu diadakannya pengkajian ulang pelaksanaan kurikulum muatan lokal Bahasa Using dan memerlukan evaluasi juga pembaharuan secara menyeluruh. Penelitian akan memberikan masukan pada program yang sudah ada.
\end{abstract}

Kata kunci: evaluasi kurikulum, kurikulum muatan lokal, bahasa using

Program pendidikan di sekolah perlu memberikan wawasan yang luas pada peserta didik tentang keistimewaan pada masing-masing lingkungan tempat tinggalnya. Pengenalan keadaan daerah kepada peserta didik memungkinkan mereka untuk lebih mengenal lingkungannya. Keadaaan daerah adalah segala sesuatu yang berada di daerah tertentu yang berkaiatan dengan lingkungan alam, lingkungan sosial ekonomi dan lingkungan sosial budaya (Purwanti, 2015). Salah satu keistimewaan yang harus diajarkan kepada para siswa adalah bahasa daerah. Pembelajaran bahasa daerah kepada siswa bertujuan untuk memperoleh nilai-nilai yang diperlukan untuk pembentukan kepribadian bangsa (Wibawa, 2007). Berdasarkan pendapat tersebut pembelajaran bahasa daerah sangat penting untuk dikembangkan bagi siswa khususnya bagi siswa sekolah dasar.

Pengenalan dan pengembangan lingkungan melalui pendidikan diarahkan untuk menunjang peningkatan kualitas sumber daya manusia. Sesuai dengan Permendiknas Nomor 22 Tahun 2006 tentang Standar Isi menyatakan bahwa Kurikulum Tingkat Satuan Pendidikan (KTSP) selain memuat beberapa mata pelajaran, juga terdapat mata pelajaran Muatan Lokal (Mulok) yang wajib diberikan pada semua tingkat satuan pendidikan. Sekolah Dasar (SD) sebagai lembaga pendidikan jenjang pertama sangat tepat dijadikan sarana untuk menanamkan nilai-nilai moral dan kearifaan lokal. SD menjadi lembaga pendidikan formal yang menyelenggarakan program pendididkan 
bagi anak di usia 6 s.d. 12 tahun dimana itu merupakan fase untuk anak mulai mengenal kehidupan sosial di sekitarnya. Pendidikan di SD memberi bekal kemampuan dasar berupa pengetahuan, keterampilan, dan sikap yang disesuaikan dengan tingkat perkembangannya. SD tidak hanya membentuk sisi kognitif tetapi juga sarana membentuk sikap dan perilaku peserta didik dalam kehidupan bersosial. Di sinilah letak esensi dari pendidikan karater yang harus diterapkan di sekolah.

Bahasa Using yang digunakan di Banyuwangi sebelumnya adalah alat komunikasi bagi kaum minoritas di daerah pedalaman, kemudian berkembang menjadi bahas multietnis bagi masyarakat yang tinggal di Banyuwangi. Bahasa Using tidak hanya sebagai alat komunikasi suku Osing saja tetapi juga bagi mereka yang bersuku Jawa, Madura, dan bali yang tinggal di Banyuwangi. Penggunaan bahasa Using aktif berada di 13 kecamatan dari 24 kecamatan yang ada di Banyuwangi. Dalam dunia pendidikan setelah disandurkan menjadi bentuk sastra dan bahasa tulis upaya pelestarian Bahasa Using di dunia pendidikan semakin gencar. Tahun 1997 awal kebijakan memasukkan Bahasa Using dalam muatan lokal percobaan dilakukan di tiga sekolah dasar di tiga kecamatan, yaitu Kecamatan Banyuwangi, Kecamatan Rogojampi, dan Kecamatan Kabat hingga saat ini digunakan lebih dari 200 sekolah dasar di Kabupaten Banyuwangi sebagai pelajaran muatan lokal.

\section{METODE}

Penelitian ini menggunakan pendekatan deskriptif kualitatif. Penelitian dilaksanakan di SDN 1 Kertosari Banyuwangi. Data yang dikumpulkan bukan berupa angka-angka, melainkan data tersebut berasal dari naskah wawancara, catatan lapangan, dokumen pribadi, catatan memo, dan dokumen resmi lainnya. Oleh karena itu, penggunaan pendekatan kualitatif dalam penelitian ini adalah dengan mencocokkan antara realita empirik dengan teori yang berlaku dengan menggunakkan metode diskriptif karena data yang diperoleh dan dilaporkan dalam bentuk tulisan (Gunawan, 2014). Peneliti menginterpretasikan fenomena-fenomena yanga ada di lapangan dan mencari maknanya (Gunawan, 2014).

\section{HASIL}

SDN 1 Kerosari telah mampu mengembangkan standar kompetensi (SK), kompetensi dasar (KD) dalam silabus dan rencana pelaksanaan pembelajaran (RPP) juga telah dapat melaksanakan kurikulum muatan lokal Bahasa Using. Walaupun demikian berdasarkan hasil observasi dan penelitian pelajaran Bahasa Using di SDN 1 Kertosari Banyuwangi diberikan pada jenjang kelas tinggi yaitu Kelas IV, V dan VI. Observasi pelaksanaan pembelajaran Bahasa Using di Kelas IV SDN 1 Kertosari Banyuwangi. Metode yang digunakan oleh ibu Sudarsih guru Bahasa Using kelas IV adalah Tanya jawab, demonstrasi, dan ceramah.

Sedangkan sumber belajar yang digunakan dalam pembelajaran Bahasa Using di Kelas IV adalah buku paket Lancar Bahasa Using Kelas IV SD/MI, Lancar Bahasa Using Kelas V SD/MI, dan Lancar Bahasa Using Kelas VI SD/MI yang merupakan buku pegangan guru yang diterbitkan oleh PT Intan Pariwara, LKS telah terdapat gambar atau ilustrasi yang dapat membantu guru untuk menjelaskan kepada peserta didik. Pelajaran Bahasa Using di Kelas IV memiliki alokasi waktu 2 jam pelajaran atau 70 menit yang diberikan setiap satu kali seminggu.

Selain itu hambatan dari implementasi kurikulum muatan lokal Bahasa Using di SDN 1 Kertosari adalah: (1) sarana prasana yang kurang mendukung; (2) minimnya sumber belajar yang digunakan juga membuat guru kesulitan dalam menjelaskan dan memberikan materi kepada siswa, guru harus lebih memahami bahan yang ada untuk bisa dikembangkan sendiri; (3) guru pengajar Bahasa Using memiliki kesulitan dalam hal menjelaskan karena tidak mahir dalam berbahasa Using juga kurang memahami tata bahasa dalam Bahasa Using; dan (4) beberapa siswa yang merupakan pendatang dari kota lain memiliki kesulitan untuk menyerap materi pelajaran yang diberikan.

\section{PEMBAHASAN}

Landasan pelaksanaan kurikulum muatan lokal di Kabupaten Banyuwangi yang dapat digunakan adalah: (1) Undang-undang Nomor 22 Tahun 1999 tentang Pemerintahan Daerah; (2) Undang-undang Nomor 20 Tahun 2003 tentang 
Sistem Pendidikan Nasional; (3) Peraturan Pemerintah Nomor 19 Tahun 2005 tentang Standar Nasional Pendidikan; dan (4) Peraturan Daerah Banyuwangi Nomor 5 Tahun 2007 tentang Pembelajaran Bahasa Daerah di Banyuwangi. Sesuai dengan Permendiknas Nomor 22 Tahun 2006 tentang Standar Isi menyatakan bahwa KTSP selain memuat beberapa mata pelajaran, juga terdapat mata pelajaran muatan lokal (mulok) yang wajib diberikan pada semua tingkat satuan pendidikan.

Kabupaten Banyuwangi dalam usaha merencanakan muatan lokal telah menetapkan Peraturan Bupati Banyuwangi Nomor 41 Tahun 2011 tentang Rincian Tugas, Fungsi, dan Tata Kerja Dinas Pendidikan Kabupaten Banyuwangi menyatakan Bidang Pendidikan Taman Kanak-kanak (TK) dan Sekolah Dasar (SD) memiliki fungsi sebagai penyusun konsep, menetapkan pedoman pelaksanaan / pedoman teknis dan menetapkan sistem evaluasi kurikulum muatan lokal TK dan SD. Dinas Pendidikan Kabupaten Banyuwangi juga membentuk tim penyusun kurikulum untuk membantu peran Dinas Pendidikan dalam upaya pengembangan muatan lokal Bahasa Using di Banyuwangi. Mulok yang sudah ada kemudian diperdalam di tingkat kecamatan dan sekolah masing-masing. Sejak diberlakukannya Kurikulum 2013, banyak sekolah menengah pertama di Kabupaten Banyuwangi tidak lagi memasukkan Bahasa Using sebagai muatan lokal di sekolah, banyak kendala yang membuat Bahasa Using tidak lagi diajarkan di tingkat menengah pertama.

Implementasi kurikulum muatan lokal di Banyuwangi banyak menemui hambatan yaitu: (1) adanya sertifikasi guru dan dijalankannya Kurikulum 2013, maka tidak ada guru yang mengajar Bahasa Using terlebih lagi di tingkat SMP, bagi sekolah yang menerapakan kurikulum 2013 para guru harus mengajar sesuai dengan ijazahnya, sedangkan tingkat universitas belum ada jurusan yang mengkhususkan Bahasa Using; (2) terbitnya Peraturan Gubernur Jawa Timur Nomor 19 Tahun 2014 tentang Mata Pelajaran Bahasa Daerah sebagai Muatan Lokal Wajib di Sekolah/ Madrasah, hanya memfasilitasi dua Bahasa yaitu Jawa dan Madura sebagai pelajaran muatan lokal, sehingga Bahasa Using tidak memiliki landasan hukum; dan (3) kurang lebih sekitar 5 tahun ini mulok Bahasa Using tidak mendapat anggaran. Akhirnya tidak bisa dilakukan penataran guru, upgrade info terbaru ataupun menyusun materimateri baru (Rijantho, 2012). Implementasi muatan lokal pada pendidikan dasar dapat dikatakan masih relatif baru, sehingga berbagai persoalan dalam kurikulum ini masih menyisakan berbagai problematika (Rijantho, 2012). Persoalan dalam implementasi kurikulum muatan lokal sampai saat ini cukup pelik. Hal ini berkaitan dengan semua aspek perencanaan, pelaksanaan dan evaluasinya.

\section{KESIMPULAN DAN SARAN}

Kurikulum muatan lokal Bahasa Using diharapkan tidak hanya sebagai pelajaran muatan lokal saja melainkan memberikan peran penting dalam pembentukan dan pembinaan karekter peserta didik terhadap nilai-nilai kebudayaan daerah Banyuwangi. Dilihat dari tenaga pengajar yang banyak tidak memiliki kemamapuan berbahasa Using yang mahir, maka pemerintah melalui Dinas Pendidikan perlu menyelenggarakan team teaching untuk dijadikan sebagai alternatif dan dapat dipikirkan sebagai solusi pengembangannya. Harus ada kerjasama terpadu antara guru, pembina, pelaksana lapangan dan nara sumber.

Mengacu dari segi proses belajar mengajar pelaksanaan muatan lokal pengajar dapat menggunakan pendekatan proses dan pendekatan kontekstual. Melalui strategi pembelajaran kontekstual, peserta didik dapat menggunakan sumber belajar dari lingkungan dan berperan lebih aktif dalam mengumpulkan pengetahuan. Namun dalam praktiknya kompetensi guru-guru dalam menerapkannya masih merupakan persoalan besar yang harus ditangani lebih lanjut. Sekolah dan pihak terkait harus mulai mencari solusi dari beberapa kendala yang ditemuan di lapangan. Pemerintah melalui Dinas Pendidikan harus mengkaji ulang pelaksanaan kurikulum muatan lokal Bahasa Using. Saat ini kurikulum muatan lokal Bahasa Using memerlukan evaluasi dan pembaharuan, baik pada proses perencanaan, pelaksanaan hingga evaluasi.

\section{DAFTAR RUJUKAN}

Gunawan, I. 2014. Metode Penelitian Kualitatif: Teori dan Praktik. Jakarta: PT Bumi Aksara. 
Peraturan Daerah Banyuwangi Nomor 5 Tahun 2007 tentang Pembelajaran Bahasa Daerah di Banyuwangi. 2007. Banyuwangi: Pemerintah Kabupaten Banyuwangi.

Peraturan Gubernur Jawa Timur Nomor 19 Tahun 2014 tentang Mata Pelajaran Bahasa Daerah sebagai Muatan Lokal Wajib di Sekolah/Madrasah, (Online), (http://www. mebermutu.org/admin/lampiran/pergub-no19-tahun-2014-mulok1.pdf), diakses 23 Juni 2016.

Peraturan Pemerintah Nomor 19 Tahun 2005 tentang Standar Nasional Pendidikan. 2006. Jakarta: Sinar Grafika.

Permendiknas Nomor 22 Tahun 2006 tentang Standar Isi. 2006. Jakarta: Kementerian Pendidikan Nasional.

Purwanti, E. 2013. Peningkatan Kemampuan Guru Sekolah Dasar Muhammadiyah dalam Pengembangan Kurikulum Muatan Lokal. Jurnal Pemikiran dan Pengembangan Sekolah Dasar, 1(1), 15-21.
Rijantho,A.2012.Implementasi Kurikulum Muatan Lokal, (Online), (http://www.kumpulgurusdl. blogspot.com/2012/10/implementasi-kurmuatan-lokal.html), diakses 10 April 2015.

Sukmadinata, N. S. 2011. Metode Penelitian Pendidikan. Bandung: PT Remaja Rosdakarya.

Undang-undang Nomor 20 Tahun 2003 tentang Sistem Pendidikan Nasional. 2004. Bandung: Citra Umbara.

Undang-undang Nomor 22 Tahun 1999 tentang Pemerintahan Daerah. 2000. Jakarta: Fokus Media.

Wibawa, S. 2007. Implementasi Pembelajaran Bahasa Daerah sebagai Muatan Lokal. Yogyakarta: Universitas Negeri Yogyakarta. 